\title{
木ねじの形状が軽軟材の引き抜き性能に及ぼす影響 INFLUENCE OF WOOD SCREW SHAPE ON WITHDRAWAL PERFORMANCE IN SOFT AND LIGHT WOOD
}

\author{
白 惠 琇*, 森田秀樹**, 飯 村 豊***, 今井 富士夫**** \\ Hei-Soo BAEK, Hideki MORITA, Yutaka IIMURA \\ and Fujio IMAI
}

\begin{abstract}
An experimental investigation was conducted to clarify the influence of wood screw shape on withdrawal performance as a fundamental step to develop a new wood screw, which is appropriate for soft and light wood. The characteristic results can be summarized as follows: (1) The improvement rate of withdrawal resistance by the penetration of unthreaded shank portion in Sugi was about two times higher than that in Douglas-fir. (2) The increase of thread minor diameter to the same thread major diameter in Sugi brought improvement in withdrawal resistance in contrast with the result in Redwood.
\end{abstract}

Keywords : Soft and light wood, Wood screw, Shape factor, Withdrawal performance 軽軟材，木ねじ，形状因子，引き抜き性能

1.はじめに

\section{1 研究背景 ·目的}

循環型社会を目指すグリーンサプライチェーンの構築のために、 早生資源の有効利用が望まれる。しかし、宮崎スギのように生長が 早い木材は比較的軽くて軟らかいため ${ }^{4}$ 、建築構造材として利用す るにあたり接合性能の低さが大きな障害となっている。さらに、接 合性能の低さによる接合具の必要本数増加は、軸組コストに与える 影響が大きい接合金物 5)を大型化・重量化させる悪循環に陥り、比 較的比重が高くて硬い木材を構造材として用いる場合に比べて軸組 コストを上昇させる原因にもなっている。したがって、早生資源を 活かした建築物の木造化を推進するためには、軽軟材に最適な接合 技術の研究が必要不可欠である。

木材の接合に用いられる接合具は様々なものがあるが、本研究で は木ねじを研究対象にした。ここで言う木ねじは、木材または木質 材料におねじだけで止めるねじの総称を指し、日本工業規格に定め る狭義の木ねじ 6)のみならず、コーチねじ 7)、コーススレッド、接 合金物止めつけ用礼じ8 10)などを含み、さらには木ねじに代用され るタッピンねじ7), 11)ども含む。木対じは釘と比較して引き抜き抵
抗が大きく、ボルトと比較して初期ガタが小さいという特徵がある。 また、電動ドライバーの発達やリサイクルの推進を背景に施工性・ 解体性が評価され、造作用途（建具や家具の止めつけなど）のみな らず構造用途（ボードや接合金物の止めつけなど）においてもその 利用が拡大しつつある 12 )

本研究では、「公共建築物等における木材の利用の促進に関する法 律」の施行によりスギ利用の必要性が高まりつつあることや木質構 造の主要構造部材における木ねじの利用増加に伴って信頼性の高い 木ねじが求められるようになっていることなどの現状を考慮し、軽 軟材の接合に有効な木ねじの開発を目的としている。

\section{2 研究範囲・方法}

構造用途に用いられる木ねじの引き抜き性能について、先行研究 や規準類では主に木材の比重、木ねじの呼び径及びねじ部のねじ込 み深さをパラメータとして評価しているが、小林 ${ }^{12)}$ はこれらが規格 類などによる一般的な形状の木补じのみを対象とした位置づけであ ると指摘している。近年には、用途拡大とともに様々な形状の木ね じが用いられるようになり、それらに着目した研究も見られるよう になってきた (表 1 参照)。

\footnotetext{
本論文は，文献 1)，2），3）に発表したものにデー夕を追加してまとめたものである。

宮崎県木材利用技術センター 研究員

宮崎大学大学院農学工学総合研究科 大学院生

** 宮崎県木材利用技術センター 主任研究員・農博

*** 宮崎県木材利用技術センター 所長・農博

**** 宮崎大学工学部社会環境システム工学科 教授・工博
} 
表 1 様々な形状の木补じを対象にした近年の先行研究一覧

\begin{tabular}{|c|c|c|c|c|}
\hline $\begin{array}{l}\text { 著者及び } \\
\text { 発表年度 }\end{array}$ & 用途 & 供試材 & 木ねじ & 検討パラメータ \\
\hline $\begin{array}{c}\text { 中谷ら }^{13)} \\
2005\end{array}$ & $\begin{array}{c}\text { 構造用途 } \\
\text { (門型ラーメンの接合) }\end{array}$ & $\begin{array}{c}\text { ベイマツ集成材 } \\
\text { E105-F300 } \\
\text { (平均比重0.53) }\end{array}$ & $\begin{array}{l}\mathrm{D}=30 \mathrm{~mm} \\
\mathrm{~L}=280 \mathrm{~mm}\end{array}$ & $\begin{array}{l}\text { 木材: 先穴直径、ねじ } \\
\text { 込み方向、縁距離 } \\
\text { 木ねじ:ねじ込み深さ }\end{array}$ \\
\hline $\begin{array}{c}\text { 徳田ら }^{14)} \\
2006\end{array}$ & $\begin{array}{c}\text { 構造用途 } \\
\text { (接合金物の止めつけ) }\end{array}$ & $\begin{array}{c}\text { スギ角材 } \\
\text { (比重 } 0.40 \sim 0.47 \text { ) }\end{array}$ & $\begin{array}{c}\text { D:5.4 } 5.5 \mathrm{~mm} \\
\text { L:45 75mm }\end{array}$ & $\begin{array}{l}\text { 木材: 比重、含水率 } \\
\text { 木ねじ: 締め付けトルク }\end{array}$ \\
\hline $\begin{array}{c}\text { 小林 }^{15)} \\
2008\end{array}$ & 構造用途 & $\begin{array}{c}\text { スギ板材 } \\
\text { (平均比重 } 0.36 \text { ) } \\
\text { ツガ板材 } \\
\text { (平均比重 } 0.50 \text { ) }\end{array}$ & $\begin{array}{c}\mathrm{D}: 4.5 \sim 5.5 \mathrm{~mm} \\
\mathrm{~L}: 27.5 \sim 101.1 \mathrm{~mm} \\
\end{array}$ & $\begin{array}{l}\text { 木ねじ:山径、谷径、 } \\
\text { ピツチ、先端部形状な } \\
\text { ど(各形状子を独立的に } \\
\text { 制御していないか、、相開の } \\
\text { 低い多種の市販ねじ使用) }\end{array}$ \\
\hline $\begin{array}{l}\text { 水野ら } \\
2008\end{array}$ & $\begin{array}{c}\text { 構造用途 } \\
\text { (ボードの止めつけ) }\end{array}$ & $\begin{array}{c}\text { スギ板材 } \\
\text { (平均比重 } 0.35 \text { ) }\end{array}$ & $\begin{aligned} \mathrm{D} & =3.8 \mathrm{~mm} \\
\mathrm{~L} & =38 \mathrm{~mm}\end{aligned}$ & $\begin{array}{l}\text { 木材: 比重、平均年輪 } \\
\text { 幅、晩材厚さの合計、 } \\
\text { 晚材の数 } \\
\text { 木ねじ:ピツチ(ピッチが } \\
\text { 粗いコーススレッド使用) }\end{array}$ \\
\hline $\begin{array}{c}\text { 村上ら } \\
2009 \\
\end{array}$ & 構造用途 & $\begin{array}{l}\text { スプル一ス板材 } \\
\text { (平均比重 } 0.44 \text { ) }\end{array}$ & \begin{tabular}{|c|} 
D:4.13 5.77mm \\
L:47 $65.2 \mathrm{~mm}$
\end{tabular} & $\begin{array}{l}\text { 木ねじ: ねじ山と木材と } \\
\text { の単位有効接触面積 }\end{array}$ \\
\hline $\begin{array}{c}\text { 村上ら }^{18)} \\
2010\end{array}$ & $\begin{array}{c}\text { 構造用途 } \\
\text { (門型ラーメンの接合) }\end{array}$ & $\begin{array}{l}\text { スプル一ス板材 } \\
\text { (平均比重 } 0.41 \text { ) }\end{array}$ & D:15.2 30.2mm & $\begin{array}{l}\text { 木ねじ: 径、ねじ山の高 } \\
\text { さ、ピツチ }\end{array}$ \\
\hline
\end{tabular}

本論文は、軽軟材用木衩じ開発の基礎的段階として、木敞じの形 状が軽軟材の引き抜き性能に及ぼす影響について実験的に検討した 結果を報告するものである。ここでは、木ねじを構成する形状因子 を詳細に分類した上で、各形状因子をパラメータとする引き抜き試 験を行った。
供試材には、軽軟材の代表として高温・多雨で日射量が多い宮崎 で植林されたスギ（Cryptomeria japonica (L.f.) D.Don）を用いた が、軽軟材特有の傾向を明らかにするため高比重材（ここでは、木 質構造設計規準による J1 グループ：比重が 0.50 程度のもの） 19) と 称されるベイマツ（Pseudotsuga menziesii (Mirb.) Franco）及び ヨーロッパアカマツ (Pinus sylvestris L.) についても同様に引き 抜き試験を行い、比較検討した。

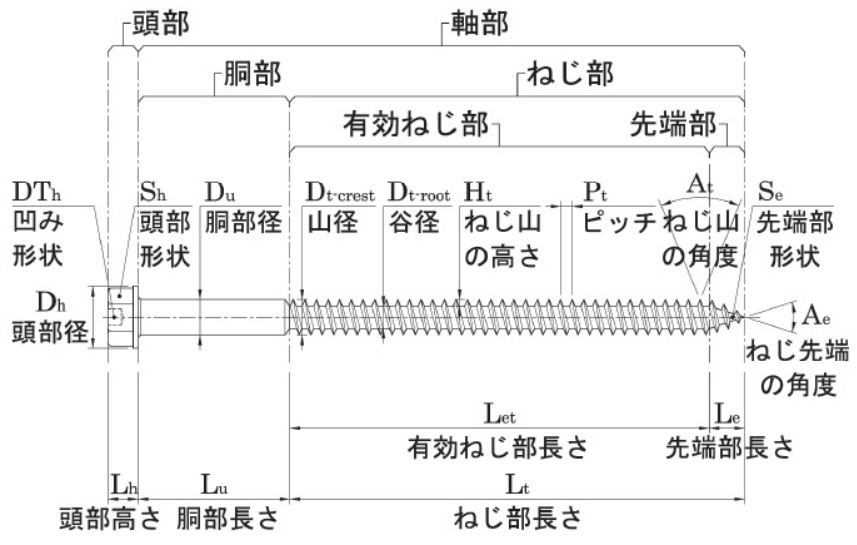

図 1 木衫じ各部の形状因子

表 2 木礼じの仕様詳細

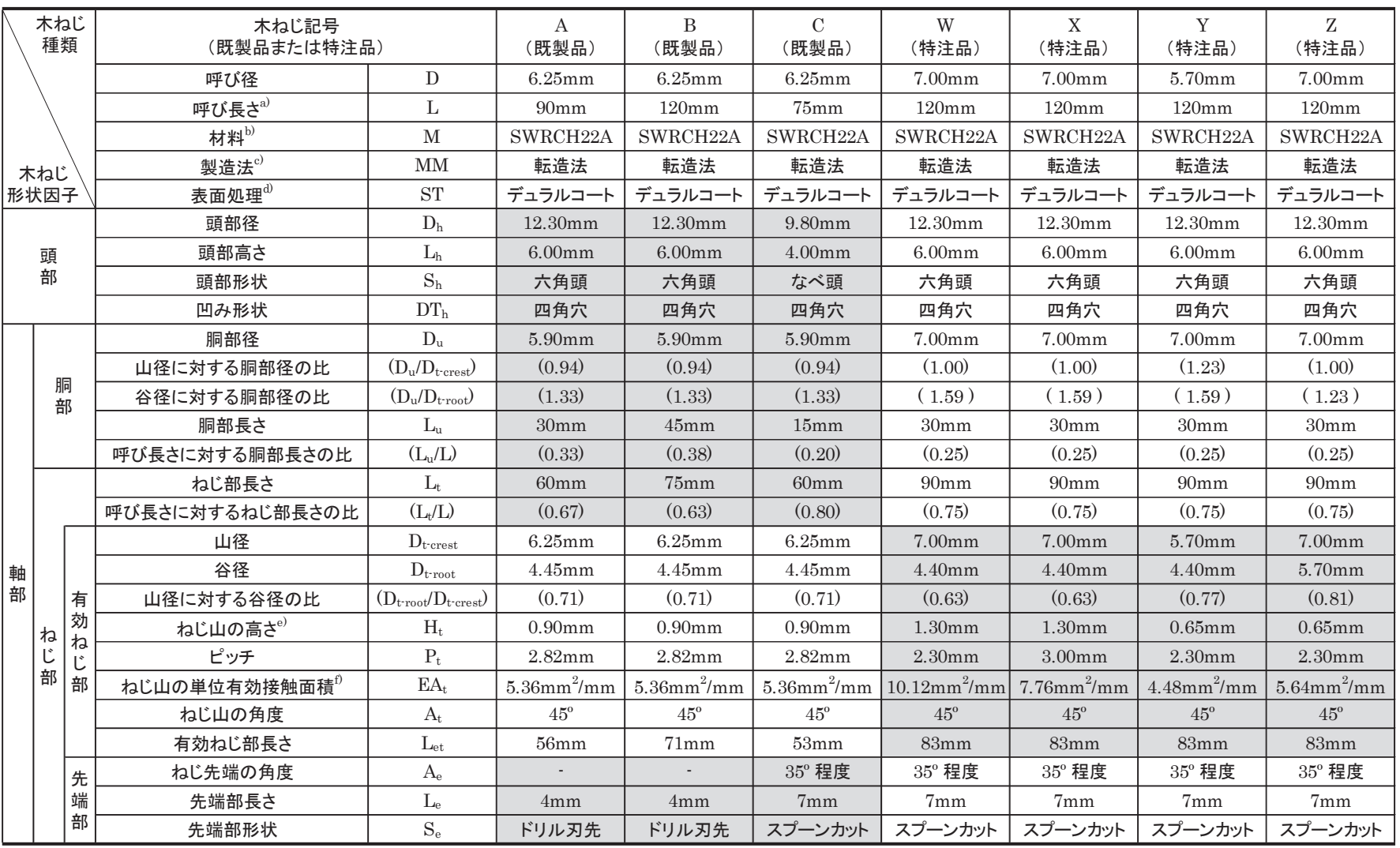

注) a) $\mathrm{L}=\mathrm{L}_{\mathrm{u}}+\mathrm{L}$

b) SWRCH: JIS G 3507(冷間圧造用炭素鋼線材; Carbon steel wire rods for cold heading and cold forging)

c）ねじの製造法は、転造法と切削法に大別できる。

転造法:ねじ山が刻んでいる転造ダイスを線材に押しつけながら転がすことでねじ山を成形する方法

切削法: 超硬質の刃先で線材を回転させながら削り落とすことでねじ山を成形する方法

d）デュラルコート:亜鉛めつきに特殊塗料を塗装した複合被膜による建築接合金物の防錆防食技術

e) $\mathrm{H}_{\mathrm{t}}=\left(\mathrm{D}_{\mathrm{t} \text {-crest }}-\mathrm{D}_{\mathrm{t} \text {-root }}\right) \div 2$

f) $\mathrm{EA}_{\mathrm{t}}=\left\{\left(\mathrm{D}_{\mathrm{t} \text {-crest }} \div 2\right)^{2}-\left(\mathrm{D}_{\mathrm{t} \text {-root }} \div 2\right)^{2}\right\} \times \pi \div \mathrm{p}$ 
木ねじは、図 1 に示すように大きく 3 つの部分に分類することが できる。すなわち、(1)締め付けのためにドライバーとの連結部を有 する頭部、(2)軸部外面にねじ切り加工がされていない胴部、(3)軸部 外面に螺旋状の衫じ山を有するねじ部である。さらに、ねじ部は、 木部への食い付きを良好にするための先端部と先端部を除く有効秝 じ部に分類することができる。なお、各部の形状因子として、(1)頭 部においては、頭部径・頭部高さ・頭部形状など、(2)胴部において は、胴部径・胴部長さなど、(3)称じ部においては、山径・谷径・ね じ山の高さ・ピッチ・㸚じ山の角度・先端部形状などを挙げること ができる7)。本論文の 2 章では、有効称じ部以外の形状因子として 胴部長さ・先端部形状、3 章では、有効称じ部の形状因子としてピ ッチ・ねじ山の高さ・谷径をパラメータとする引き抜き試験を行い、 各形状因子と引き抜き性能との関係について検討した。2 章と 3 章 の実験に用いた木致じは、主に接合金物の止めつけ用を想定し、呼 び径 5.7 7.0mm、呼び長さ $75 \sim 120 \mathrm{~mm}$ の範囲とした。表 2 にその 仕様詳細を示す。

\section{2. 有効ねじ部以外の形状因子に関する実験的検討}

一般的に、木致じの引き抜きに対する抵抗は有効祇じ部に負うと ころが大きいと言われているが、軽軟材用の新しい木ねじを開発す る目的から、2 章では改めて有効㸚じ部以外の形状因子、例えば、 胴部長さ・先端部形状について検討する。

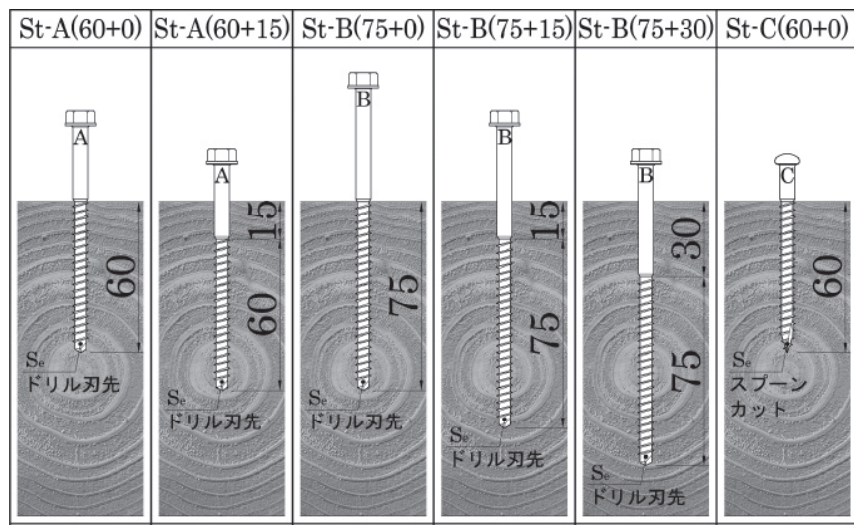

\begin{tabular}{|l|l|l|l|l|l|}
\hline $\mathrm{Bt}-\mathrm{A}(60+0)$ & $\mathrm{Bt}-\mathrm{A}(60+15)$ & $\mathrm{Bt}-\mathrm{B}(75+0)$ & $\mathrm{Bt}-\mathrm{B}(75+15)$ & $\mathrm{Bt}-\mathrm{B}(75+30)$ & $\mathrm{Bt}-\mathrm{C}(60+0)$ \\
\hline
\end{tabular}

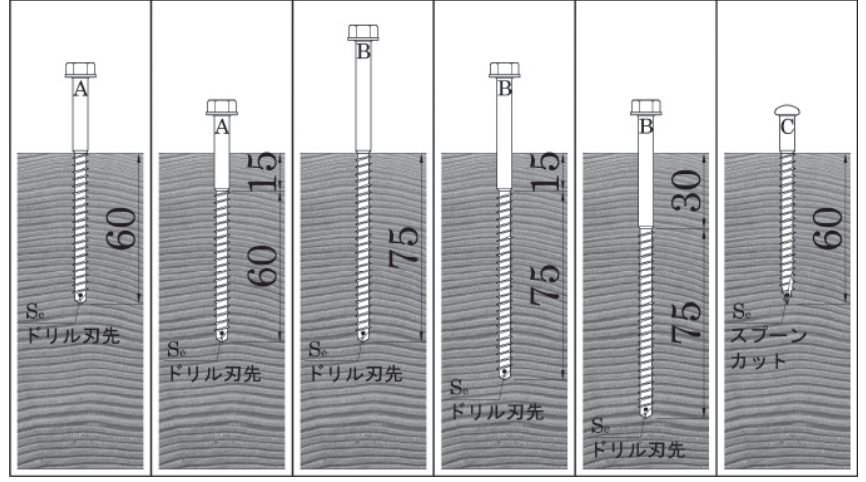

注) 試験体名は、「供試材種類一木ねじ種類(ねじ部のねじ込み深さ十胴部のねじ 込み深さ)」の形で表す。

供試材種類: $\mathrm{St}$ (スギの角材), $\mathrm{Bt}$ (ベイマッの角材)

木ねじ種類: A, B, C

ねじ部のねじ込み深さ: $60 \mathrm{~mm}, 75 \mathrm{~mm}$

胴部のねじ込み深さ: $0 \mathrm{~mm}, 15 \mathrm{~mm}, 30 \mathrm{~mm}$

図 2 試験体概要（胴部長さ・先端部形状の検討）

\section{1 実験概要}

供試材には、スギとベイマツの製材（角材）を用いた。スギは幅 $125 \mathrm{~mm} \times$ 厚さ $125 \mathrm{~mm} \times$ 長さ $1000 \mathrm{~mm}$ の芯持ち材を切らずにそのま ま用い、後述する 6 条件を振り分けた。気乾比重は $0.414 \pm 0.009$ 、 年輪幅は $5.3 \pm 0.9 \mathrm{~mm}$ 、含水率は $12.7 \pm 0.4 \%$ でった。ベイマツは幅 $120 \mathrm{~mm} \times$ 厚さ $120 \mathrm{~mm} \times$ 長さ $1000 \mathrm{~mm}$ の芯去り材（可能な限り二方 柾を選別したもの）を長さ方向に 10 分割した後、比重を測定し、 各グループ間の比重差（比重の平均と標準偏差）が最小となるよう に 6 グループに振り分けた。気乾比重は $0.622 \pm 0.014$ 、年輪幅は $2.5 \pm 0.4 \mathrm{~mm}$ 、含水率は $15.1 \pm 1.8 \%$ あ゙あた。ここで、供試材標本の 各值は「平均土標準偏差」の形で表したものである。木衫じは、市 販されている既製品の中から有効衫じ部の形状因子が同一条件にな るように選定した $\mathrm{A}, \mathrm{B}, \mathrm{C}$ （表 2 参照）の 3 種類を用いた。

試験体概要を図 2 に示寸。胴部長さによる影響は、木㸚じ $\mathrm{A}$ と木 ねじ $\mathrm{B}$ を用いて胴部の漦じ込み深さを $0 \mathrm{~mm}, 15 \mathrm{~mm}, 30 \mathrm{~mm}$ として 検討した。先端部形状による影響は、木㸚じ $\mathrm{A}$ と木㸚じ $\mathrm{C}$ を用いて ドリル刃先とスプーンカットによる違いを比較した。木ねじの形状 因子を上記のように設定した 6 条件について、スギとベイマツの 2 樹種を用い、全 12 種類の試験体を準備した。ここで、試験体数は 1 種類につき各 10 体とした。

図 3 に試験体図を示寸。木ねじのねじ込みは、スギの場合、板目 四面の任意の面から中心の髄に向かう方向に、ベイマツの場合、板 目二面の木表から木裏に向かう方向とし、いずれも年輪と直角にな るように礼じ込んだ。なお、先穴を開けずに電動インパクトドライ バーを使用してねじ込むが、垂直に㸚じ込むためにドライバーガイ
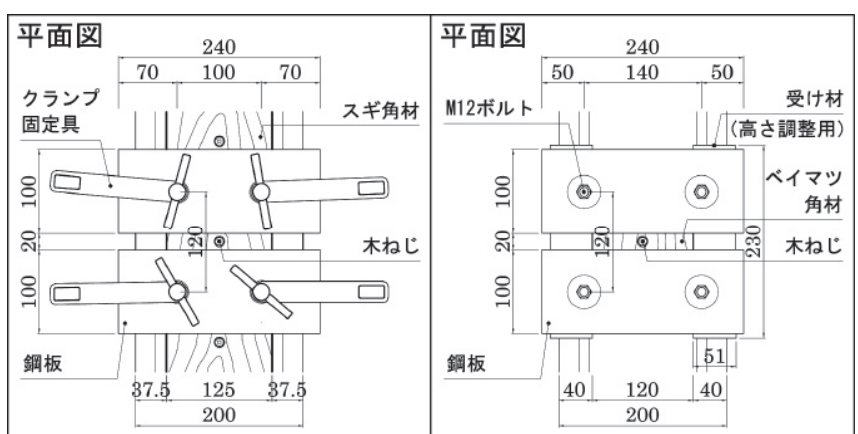

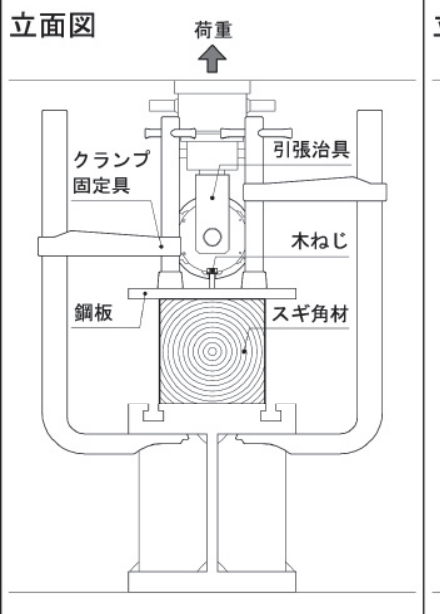

(a) スギ試験体

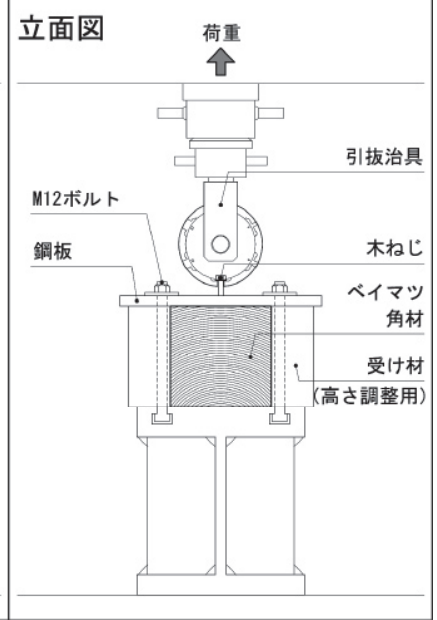

（b）ベイマツ試験体
図 3 試験体図（胴部長さ・先端部形状の検討） 
ドを用いた。実験は、試験体を固定した後、木ねじの頭部に治具を 引っ掛け、変位速度 $1 \mathrm{~mm} / \mathrm{min}$ の静的単調加力とした。この時、ク ロスヘッド移動量を測定し、これを木ねじの引き抜き変位とした。 最大荷重に達した後、荷重が 8 割以下まで低下した時点で実験を終 了した。なお、木ねじのねじ込み後、加力を行うまでに 10 分 1 時 間要した。また、試験体の固定方法はスギの場合とベイマツの場合 で異なるが、実験の効率を考慮し、図 3 の(a)に示すクランプ固定具 による方法から(b)に示すボルト締めによる方法に改善したもので ある。

\section{2 実験結果 $\cdot$ 考察}

(1) 実験結果

試験体の平均荷重一変位曲線を図 4 に示し、最大引き抜き耐力を 表 3 に示しす。なお、最大引き抜き耐力については、標本の実験結 果が母集団に対して統計的に信頼性をもっているかを評価するため に有意差検定を行った。

先ず、スギの引き抜き試験結果を以下に述べる。

(1)スギにおける胴部長さの影響 : ねじ部と共に胴部をねじ込んだ試 験体 St-A(60+15)は、㸚じ部のみをねじ込んだ試験体 St-A(60+0)に
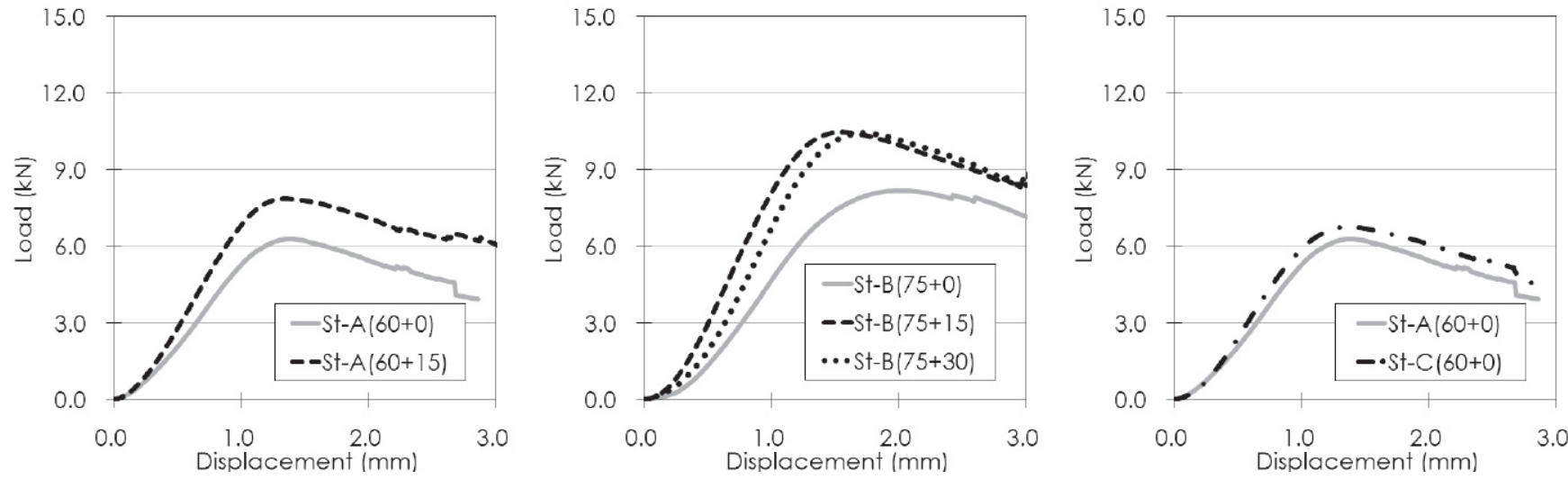

（a）スギにおける胴部長さの影響
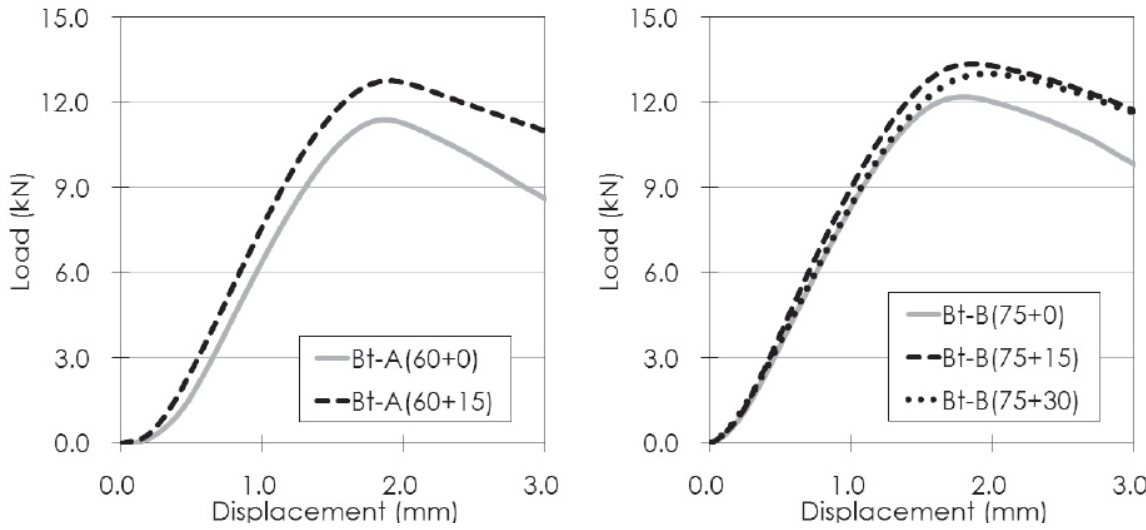

（b）スギにおける先端部形状の影響

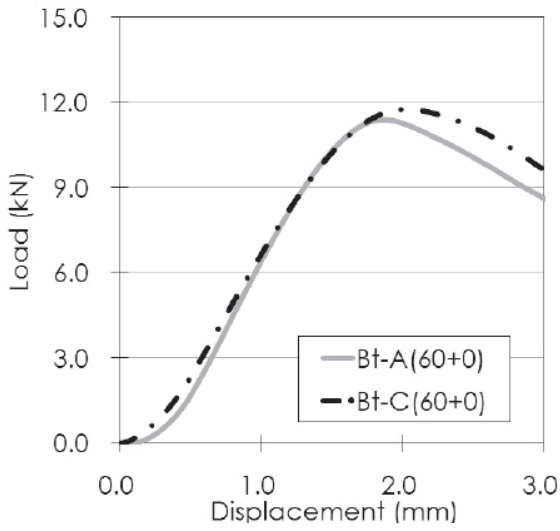

(d) ベイマツにおける先端部形状の影響

図 4 平均荷重一変位曲線（胴部長さ・先端部形状の検討）

表 3 最大引き抜き耐力の比較（胴部長さ・先端部形状の検討）

(a) スギ試験体

\begin{tabular}{|c|c|c|c|c|c|}
\hline & & \multicolumn{2}{|c|}{ St-A(60+0) } & \multicolumn{2}{|c|}{$\mathrm{St}-\mathrm{B}(75+0)$} \\
\hline & & 平均值(1) & $6.41 \mathrm{kN}$ & 平均值 (3) & $8.68 \mathrm{kN}$ \\
\hline & & 変動係数 & $7 \%$ & 変動係数 & $11 \%$ \\
\hline \multicolumn{2}{|c|}{ St-A(60+15) } & (1)と(2)の間の & ๑ & \multirow{3}{*}{\multicolumn{2}{|c|}{ - }} \\
\hline 平均值(2) & $8.11 \mathrm{kN}$ & 有意差検定 & (4) & & \\
\hline 変動係数 & $7 \%$ & (1)に対する(2)の比 & $126 \%$ & & \\
\hline \multicolumn{2}{|c|}{ St-B $(75+15)$} & \multirow{3}{*}{\multicolumn{2}{|c|}{ - }} & (3)と(4)の間の & ค \\
\hline 平均値(4) & $10.68 \mathrm{kN}$ & & & 有意差検定 & (4) \\
\hline 変動係数 & $8 \%$ & & & (3)に対する(4)の比 & $123 \%$ \\
\hline \multicolumn{2}{|c|}{ St-B $(75+30)$} & \multirow{3}{*}{\multicolumn{2}{|c|}{ - }} & (3)と(5)の間の & ๑ \\
\hline 平均值(5) & $10.55 \mathrm{kN}$ & & & 有意差検定 & (i) \\
\hline 変動係数 & $6 \%$ & & & (3)に対する(5)の比 & $122 \%$ \\
\hline \multicolumn{2}{|c|}{ St-C(60+0) } & (1)と(6)の間の & Y & \multirow{3}{*}{\multicolumn{2}{|c|}{ - }} \\
\hline 平均值 (6) & $6.82 \mathrm{kN}$ & 有意差検定 & $\lambda$ & & \\
\hline 変動係数 & $6 \%$ & (1)に対する(6)に比 & $106 \%$ & & \\
\hline
\end{tabular}

注) @ : 有意差有り $(\alpha=0.01) 、 \bigcirc$ : 有意差有り $(\alpha=0.05) 、 \times$ : 有意差無し (b) ベイマツ試験体

\begin{tabular}{|c|c|c|c|c|c|}
\hline & & \multicolumn{2}{|c|}{$\mathrm{Bt}-\mathrm{A}(60+0)$} & \multicolumn{2}{|c|}{$\mathrm{Bt}-\mathrm{B}(75+0)$} \\
\hline & & 平均値(1) & $11.54 \mathrm{kN}$ & 平均値(3) & $12.28 \mathrm{kN}$ \\
\hline & & 変動係数 & $7 \%$ & 変動係数 & $6 \%$ \\
\hline \multicolumn{2}{|c|}{$\mathrm{Bt}-\mathrm{A}(60+15)$} & (1)と(2)の間の & & \multirow{3}{*}{\multicolumn{2}{|c|}{ - }} \\
\hline 平均値(2) & $12.86 \mathrm{kN}$ & 有意差検定 & (5) & & \\
\hline 変動係数 & $4 \%$ & (1)に対する(2)の比 & $111 \%$ & & \\
\hline \multicolumn{2}{|c|}{$\mathrm{Bt}-\mathrm{B}(75+15)$} & \multirow{3}{*}{\multicolumn{2}{|c|}{ - }} & (3)と(4)の間の & @ \\
\hline 平均値(4) & $13.41 \mathrm{kN}$ & & & 有意差検定 & \\
\hline 変動係数 & $5 \%$ & & & (3)に対する(4)の比 & $109 \%$ \\
\hline \multicolumn{2}{|c|}{$\mathrm{Bt}-\mathrm{B}(75+30)$} & \multirow{3}{*}{\multicolumn{2}{|c|}{ - }} & (3)と(5)の間の & ๑ \\
\hline 平均值(5) & $13.19 \mathrm{kN}$ & & & 有意差検定 & () \\
\hline 変動係数 & $4 \%$ & & & (3)に対する(5)の比 & $107 \%$ \\
\hline \multicolumn{2}{|c|}{$\mathrm{Bt}-\mathrm{C}(60+0)$} & (1)と(6)の間の & Y & \\
\hline 平均値6) & $11.86 \mathrm{kN}$ & 有意差検定 & 人 & & \\
\hline 変動係数 & $7 \%$ & (1)に対する6)に比 & $103 \%$ & & \\
\hline
\end{tabular}

注） @ : 有意差有り $(\alpha=0.01) 、 \bigcirc$ : 有意差有り $(\alpha=0.05) 、 \times$ : 有意差無し 
比べて最大引き抜き耐力が $1.70 \mathrm{kN}$ (26\%) 向上した。同様に、ね じ部と共に胴部をねじ込んだ試験体 St-B $(75+15)$ 及び St-B $(75+30)$ についても、ねじ部のみをねじ込んだ試験体 $\mathrm{St}-\mathrm{B}(75+0)$ に比べて最 大引き抜き耐力が $1.87 \sim 2.01 \mathrm{kN}(22 \sim 23 \%)$ 向上する結果となり、 胴部放じ込夕による引き抜き性能の向上効果が見られた。これらに は有意水準 $1 \%$ で有意差が認められた。ここで、実験に用いた木水 じの谷径に対する胴部径の比は 1.33 であった。一方、胴部のねじ込 み深さが異なる試験体 St-B(75+15) と試験体 St-B(75+30)では、荷 重一変位挙動や最大引き抜き耐力にほとんど差が認められなかった。 (2)スギにおける先端部形状の影響: 先端部形状のみが異なる試験体 $\mathrm{St}-\mathrm{A}(60+0)$ と試験体 $\mathrm{St}-\mathrm{C}(60+0)$ では、最大引き抜き耐力に $0.40 \mathrm{kN}$ （6\%）の差が生じていたが、統計的に有意な差（有意水準 5\%）は 認められなかった。したがって、ドリル刃先とスプーンカットの先 端部形状の違いは引き抜き性能に大きな影響を及ぼさないと推察さ れる。

次に、ベイマツに対する引き抜き試験結果を示す。

(3)ベイマツにおける胴部長さの影響 : 試験体 Bt-A(60+15)は、試験 体 Bt-A(60+0)に比べて最大引き抜き耐力が $1.32 \mathrm{kN}$ (11\%) 向上し、 試験体 $\mathrm{Bt}-\mathrm{B}(75+15)$ 及び $\mathrm{Bt}-\mathrm{B}(75+30)$ についても、試験体 $\mathrm{Bt}-\mathrm{B}(75+0)$ に比べて最大引き抜き耐力が $0.91 \sim 1.13 \mathrm{kN} （ 7 \sim 9 \%)$ 向 上した。これらには有意水準 $1 \%$ で有意差が認められたが、胴部の ねじ込みによる最大引き抜き耐力の向上率は、スギの場合に対して 半分程度にとどまった。なお、胴部のねじ込み深さが異なる試験体 $\mathrm{Bt}-\mathrm{B}(75+15)$ と試験体 $\mathrm{Bt}-\mathrm{B}(75+30)$ では、スギの結果と同様、引き 抜き性能にほとんど差が認められなかった。

(4) ベイマツにおける先端部形状の影響: 試験体 Bt-A(60+0) と試験体 $\mathrm{Bt}-\mathrm{C}(60+0)$ における最大引き抜き耐力の差は $0.32 \mathrm{kN}$ (3\%) と僅か で、統計的な有意差（有意水準 5\%）も認められなかった。スギの 結果と同様に、ドリル刃先とスプーンカットの先端部形状の違いは 引き抜き性能に大きな影響を及ぼさないと推察される。

(2) 考察

日本工業規格に定める木ねじ ${ }^{6}$ ののき抜き性能は、木材の基準比 重、木㸚じの呼び径（山径）及び有効祇じ部のねじ込夕深さを用い て算出するように木質構造設計規準において設計式が示されている 19)。すなわち、木対じの引き抜きに対する抵抗は有効祇じ部に負う ところが大きく、有効ねじ部以外の部分は評価しないのが一般的で あった。しかしながら、木ねじの胴部長さについて検討した実験結 果から、スギの場合は胴部ねじ込みによる最大引き抜き耐力の向上 率が 22 26\%を示し、ベイマッの 7 11\%に比べ 2 倍程度高くなった ことが確認できた。すなわち、軽軟材の場合は、引き抜き性能向上 への胴部の寄与が相対的に大きいものと推察される。その一方で、 スギとベイマツのいずれも、胴部ねじ込み深さの増加による引き抜 き性能向上に一定以上の効果は認められなかった。これは釷のよう な円筒形状の接合具の引き抜き性能が、打ち込み長さに比例して増 加することと異なる傾向であった。以上の実験結果の要因について、 割れにくく潰れやすい特性を持つ軽軟材に谷径より大きい径の胴部 をねじ込むことで同部周辺の木材が圧密され、ここでの締め付け力 が部分的に高まるためと推察される。但し、ここで用いた供試材は、 一般に建築構造材として多く流通・使用されているものを対象にし たためにスギが芯持ち材、ベイマツが芯去り材と条件が異なる。今
後、両者の引き抜き性能の向上率を定量的に比較するため、試験条 件をより厳密に揃えた追加試験を行う予定である。

\section{3. 有効ねじ部の形状因子に関する実験的検討}

前述したように、木ねじの引き抜き性能を算出する設計式に反映 されている形状因子は山径と有効礼じ部長さのみである ${ }^{19) 。 3}$ 章で は、設計式で考慮されていない形状因子、すなわち有効ねじ部のピ ッチ・漦じ山の高さ・谷径について検討する。

\section{1 実験概要}

供試材には、スギとヨーロッパアカマツの製材（板材）を用いた。 スギは幅 $100 \mathrm{~mm}$ ×厚さ $20 \mathrm{~mm}$ ×長さ $500 \mathrm{~mm}$ の板目材 35 本を長さ 方向に 4 分割してそれぞれ 4 グループに振り分けた。気乾比重は $0.398 \pm 0.033$ 、年輪幅は $3.4 \pm 1.4 \mathrm{~mm}$ 、含水率は $10.0 \pm 0.6 \%$ あった。 一方、ヨーロッパアカマツは幅 $105 \mathrm{~mm} \times$ 厚 $20 \mathrm{~mm}$ ×長さ $500 \mathrm{~mm}$ の板目材 35 本を長さ方向に 4 分割した後、比重を測定し、各グル 一プ間の比重差（比重の平均と標準偏差）が最小となるように 4 グ ループに振り分けた。気乾比重は $0.566 \pm 0.056$ 、年輪幅は $1.7 \pm 0.5 \mathrm{~mm}$ 、 含水率は $11.7 \pm 0.6 \%$ でった。木水じは、表 2 に示すように、有効 ねじ部の形状因子を 1 条件ずつ変化させて設計・製造した特注品、 $\mathrm{W}, \mathrm{X}, \mathrm{Y}, \mathrm{Z}$ の 4 種類を用いた。

試験体概要を図 5 に示す。ピッチによる影響は、木ねじ W $\left(\mathrm{P}_{\mathrm{t}}=2.3 \mathrm{~mm}\right)$ と木㸚じ $\mathrm{X}\left(\mathrm{P}_{\mathrm{t}}=3.0 \mathrm{~mm}\right)$ を、ねじ山の高さによる影 響は、木ねじ $\mathrm{W}\left(\mathrm{H}_{\mathrm{t}}=1.3 \mathrm{~mm}\right)$ と木ねじ $\mathrm{Y}\left(\mathrm{H}_{\mathrm{t}}=0.65 \mathrm{~mm}\right)$ を比較す ることで検討した。さらに、谷径による影響は、木ねじ W $\left(\mathrm{D}_{\mathrm{t}-\mathrm{root}}=4.4 \mathrm{~mm}\right)$ と木衩じ $\mathrm{Z}\left(\mathrm{D}_{\mathrm{t}-\mathrm{root}}=5.7 \mathrm{~mm}\right)$ を用いて比較検討し た。木ねじの形状因子を上記のように設定した 4 条件について、ス ギとヨーロッパアカマツの 2 樹種を用い、全 8 種類の試験体を準備

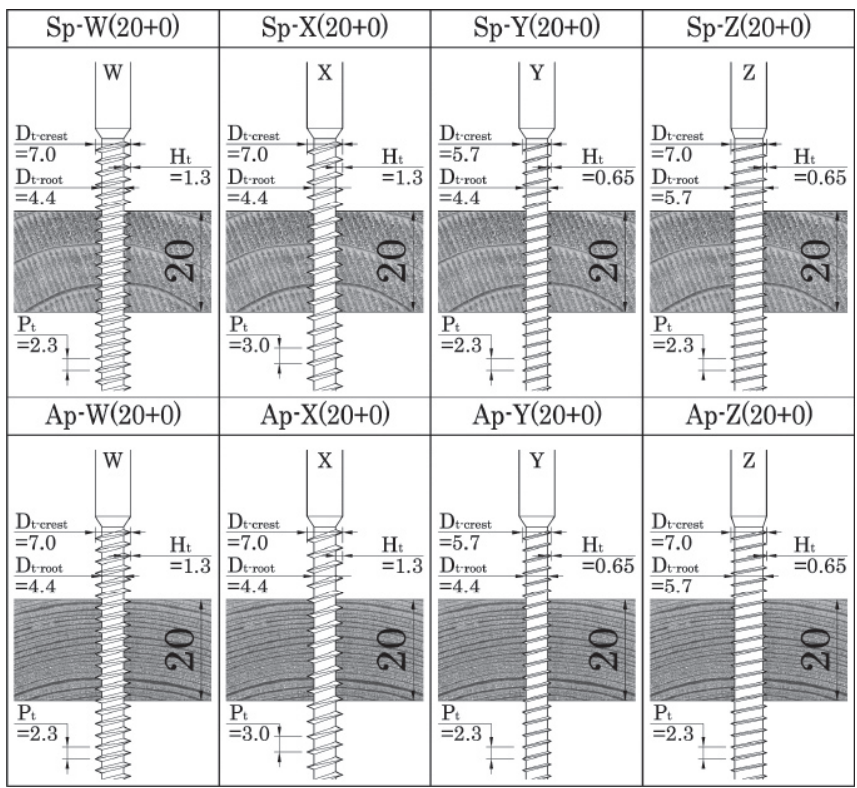

注)試験体名は、「供試材種類一木ねじ種類(ねじ部のねじ込み深さ+胴部のねじ 込み深さ)」の形で表す。

供試材種類: $\mathrm{Sp}$ (スギの板材), $\mathrm{Ap}$ (ヨーロッパアカマッの板材)

木ねじ種類: $\mathrm{W}, \mathrm{X}, \mathrm{Y}, \mathrm{Z}$

ねじ部のねじ込み深さ: $20 \mathrm{~mm}$

胴部のねじ込み深さ: $0 \mathrm{~mm}$

図 5 試験体概要（ピッチ・放じ山の高さ・谷径の検討） 
した。ここで、試験体数は、 1 種類につき各 35 体と 2 章での角材の 試験より多く確保したが、これは薄板使用により結果のバラツキが 大きくなりやすいことを考慮したためである。

図 6 に試験体図を示す。木㸚じのねじ込みは、板目面の木表から 木裏に向かって年輪と直角になる方向に行った。なお、木ねじのね じ込み方法や加力、測定などの実験方法は 2 章と同様であるが、変 位速度については $2 \mathrm{~mm} / \mathrm{min}$ に設定した。これは、試験体数に配慮 して速度を速めたほか、特別の意味はない。また、試験体の固定方 法がスギの場合とヨーロッパアカマツの場合で異なるが、これは初 期ガタを低減させるために図 6 の(a)に示寸固定治具による方法か ら(b)に示すボルト締めによる方法に改善したものである。

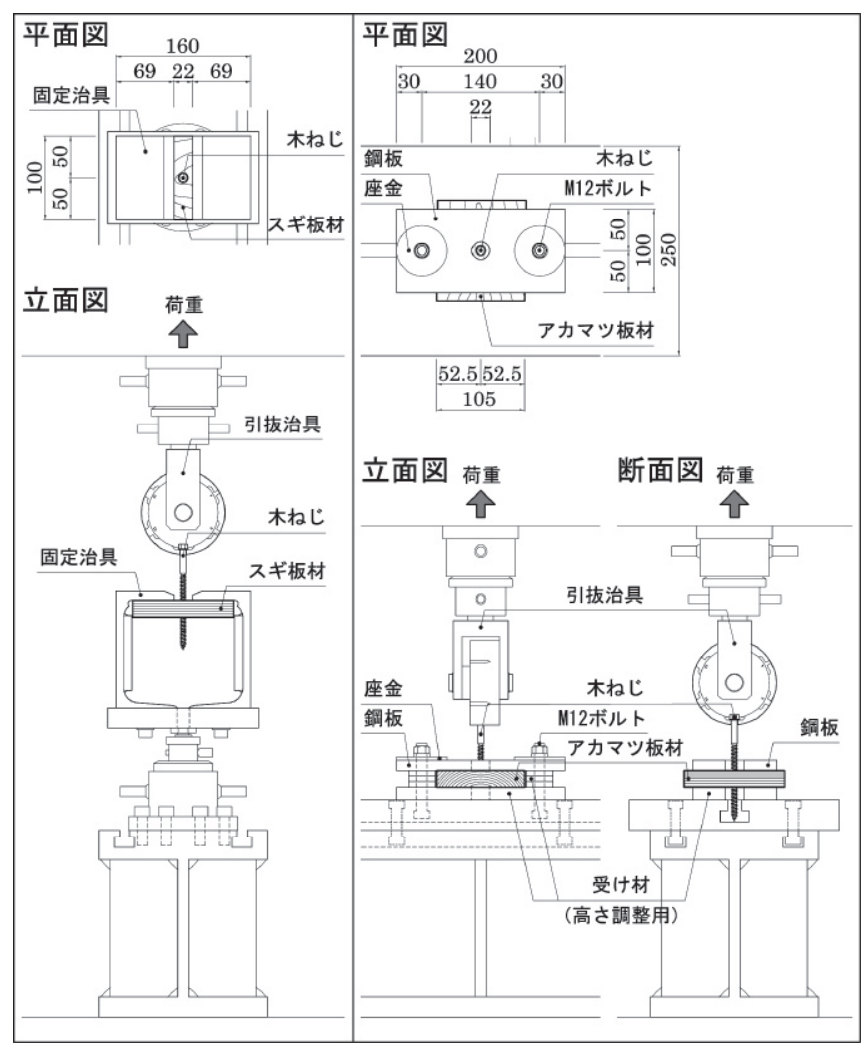

(a) スギ試験体

(b) ヨーロッパアカマツ試験体

図 6 試験体図（ピッチ・ねじ山の高さ・谷径の検討）

\section{2 実験結果・考察}

(1) 実験結果

試験体の平均荷重一変位曲線を図 7 に示し、最大引き抜き耐力を 表 4 に示す。

先ず、スギの引き抜き試験結果を以下にまとめる。

(1)スギにおけるピッチの影響：ピッチを $3.0 \mathrm{~mm} と 0.7 \mathrm{mm（30 \% )}$ 広げた試験体 $\mathrm{Sp}-\mathrm{X}(20+0)$ は、ピッチが $2.3 \mathrm{~mm}$ の試験体 $\mathrm{Sp}-\mathrm{W}(20+0)$ と比較して、最大引き抜き耐力が $0.08 \mathrm{kN}(3 \%)$ 低い值を示したが、 相互間に有意な差（有意水準 5\%）は認められず、荷重一変位挙動 もほぼ一致していた。したがって、木ねじ X と木衫じ W における ピッチ変化量の範囲内に限り、ピッチが引き抜き性能に及ぼす影響 は軽微であると推察される。

(2)スギにおけるねじ山の高さの影響 : ねじ山の高さを $0.65 \mathrm{~mm}$ と $0.65 \mathrm{~mm}(50 \%)$ 低くした試験体 $\mathrm{Sp}-\mathrm{Y}(20+0)$ は、漦じ山の高さが
$1.3 \mathrm{~mm}$ の試験体 $\mathrm{Sp}-\mathrm{W}(20+0)$ と比較して、最大引き抜き耐力が $0.18 \mathrm{kN}(7 \%)$ 低下し、相互間に $5 \%$ の有意水準で有意差が認められ た。谷径が同径である場合は、ねじ山の高さを高くすることでねじ 山による機械抵抗が増加し、引き抜き性能が向上すると考えられる。 (3)スギにおける谷径の影響 : 谷径を $5.7 \mathrm{~mm}$ と $1.3 \mathrm{~mm}$ (30\%) 大き くした試験体 Sp-Z(20+0)は、谷径が $4.4 \mathrm{~mm}$ の試験体 $\mathrm{Sp}-\mathrm{W}(20+0)$ と比較して、最大引き抜き耐力が $0.18 \mathrm{kN} （ 7 \%)$ 向上した。また、 相互間に $5 \%$ の有意水準で有意差が認められた。山径が同径である 場合は、㸚じ山の高さを低くした方が引き抜き性能の向上をもたら 寸結果となり、站じ谷による摩擦抵抗が引き抜き性能の向上に寄与 することを示唆するものであった。この結果は、試験体 $\mathrm{Sp}-\mathrm{Y}(20+0)$ と試験体 $\mathrm{Sp}-\mathrm{W}(20+0)$ を比較して得られた結果(2) と一見相反するも のであるが、これらのことから類推されることは、山径に対する谷 径の比を適切に設計することにより、㸚じ山による機械抵抗とねじ 谷による摩擦抵抗の両者を効果的に寄与させる仕様が実現し得ると いうことである。なお、木対じ Z の山径に対する谷径の比は 0.81 であり、木恎じ $\mathrm{W}$ の 0.63 より大きく、日本工業規格に定める木称 じ6)の 0.65 0.75よりもやや大きめの水準であった。

次に、ヨーロッパアカマツの引き抜き試験結果を示す。 (4)ヨーロッパアカマツにおけるピッチの影響 : ピッチを広げた試験 体 $\mathrm{Ap}-\mathrm{X}(20+0)$ は、試験体 $\mathrm{Ap}-\mathrm{W}(20+0)$ と比較して、最大引き抜き耐 力が $0.08 \mathrm{kN}$ （3\%）低い值を示したが、有意な差（有意水準 5\%） は認められなかった。スギの場合と同様に、木対じ X と木齐じ $\mathrm{W}$ におけるピッチ変化量の範囲内に限り、ピッチによる影響は軽微で あると考えられる。

(5) ヨーロッパアカマツにおけるねじ山の高さの影響 : ねじ山の高さ を低くした試験体 $\mathrm{Ap}-\mathrm{Y}(20+0)$ は、試験体 $\mathrm{Ap}-\mathrm{W}(20+0)$ と比較して、 最大引き抜き耐力が $0.41 \mathrm{kN}$ （11\%）低下した。これには $1 \%$ 有意 水準で有意差が認められた。スギの場合と同様に、ねじ山による機 械抵抗が引き抜き性能に及ぼす影響は大きいものと推察される。 (6) ヨーロッパアカマツにおける谷径の影響 : 谷径を大きくした試験 体 Ap-Z(20+0)は、試験体 $\mathrm{Ap}-\mathrm{W}(20+0)$ と比較して、最大引き抜き耐 力が $0.09 \mathrm{kN}(2 \%)$ 高い值を示したものの、これに有意な差（有意 水準 5\%) は認められなかった。このことから、ヨーロッパアカマ ツの場合、㸚じ谷による摩擦抵抗の引き抜き性能向上への寄与は、

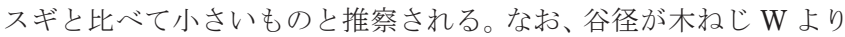
大きい木㸚じ Zを㸚じ込む際に割れが生じた試験体が数体あったこ とから、谷径が相対的に大きい木ねじを高比重材に使用する場合に は施工面で不利になる可能性があると考えられる。ここで、引き抜 き性能を評価するにあたっては、割れが生じた試験体を除外し、類 似の材に代替して行っている。

(2) 考察

村上らの先行研究によると有効ねじ部の引き抜き性能はねじ山に よる機械抵抗が大半を占め、初じ谷による摩擦抵抗を取り除くとね じ山の単位有効接触面積（螺旋状に存在するねじ山を木ねじの軸方 向に投影した面積をピッチで除したもの）に概ね比例するとの結果 が報告されている 17)。本実験においても、谷径が同径である場合、 スギとヨーロッパアカマツのいずれもねじ山の高さが高いほど高い 引き抜き性能を示しており、㸚じ山による機械抵抗と引き抜き性能 との強い相関関係が確認できた。一方、山径が同径である場合の谷 
径について検討した結果、スギは谷径の増大による最大引き抜き耐 力の向上率が $7 \%$ を示し、向上が認められなかったヨーロッパアカ マツとは対照的な傾向を示したことが確認された。すなわち、スギ の場合、谷径の増大に応じてねじ山の高さが低くなるものの、引き 抜き性能は向上する結果となった。これは、軽軟材の場合、ねじ山 による機械抵抗の低下率よりねじ谷による摩擦抵抗の増加率が大き く作用する可能性があることを示唆するものである。なお、山径、 谷径、㸚じ山の高さの形状因子は相互独立的ではないため、それぞ れを効果的に寄与させる方法として山径に対する谷径の比を適切に 設計することが考えられる。谷径の増大はねじ込む際の木材の押し 潰しを促進し、締め付け力を高める効果があると推測され、軽軟材
の場合は山径に対する谷径の比を一般的な木ねじのそれより比較的 大きく設定することで、その効果が得られやすくなると考えられる。

\section{4. まとめ}

軽軟材を建築構造材として有効利用するためには、比重差により 接合性能が低下寸る課題を改善する必要がある。本論文は、軽軟材 用木ねじ開発の基礎的段階として、木ねじの形状が軽軟材の引き抜 き性能に及ぼす影響について検討したものであり、実験結果を要約 すると以下のようになる。

(1) 有効祀じ部以外の形状因子に関する検討結果

(1)胴部長さの影響 : スギとベイマツのいずれも、ねじ部と共に胴部

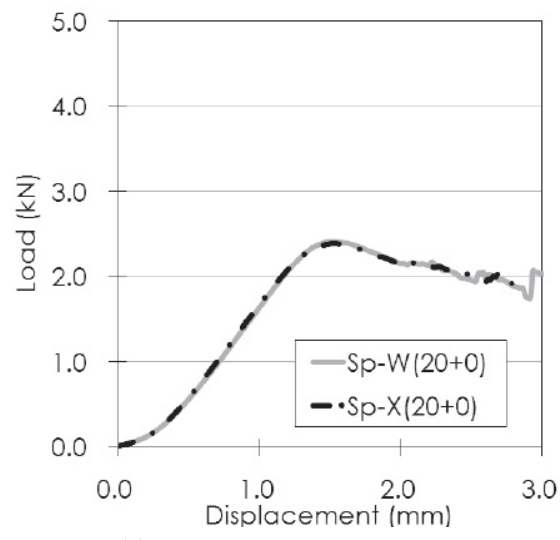

(a) スギにおけるピッチの影響

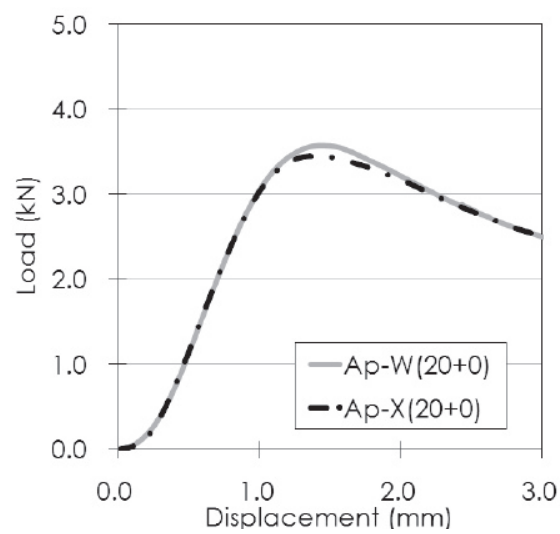

(d) ヨーロッパアカマツにおけるピッチの影響

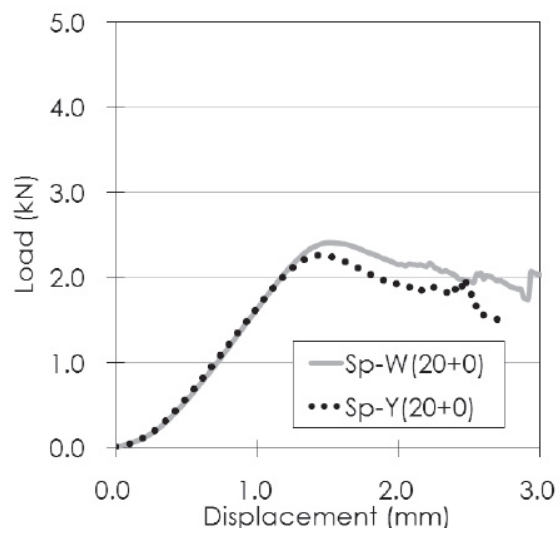

(b) スギにおけるねじ山の高さの影響

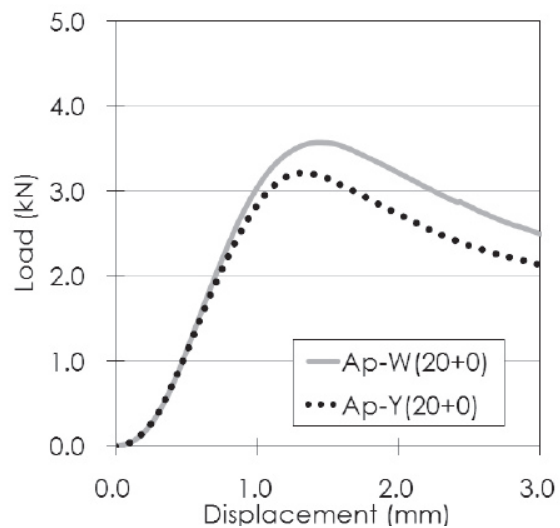

(e) ヨーロッパアカマツにおけるねじ山の高さの影響

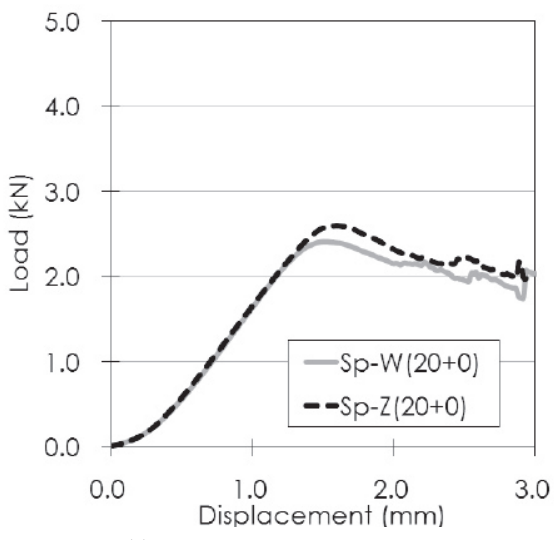

(c) スギにおける谷径の影響

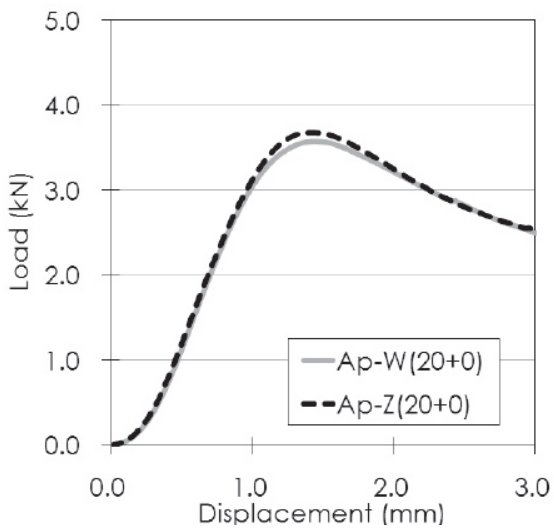

図 7 平均荷重一変位曲線（ピッチ・ねじ山の高さ・谷径の検討）

表 4 最大引き抜き耐力の比較（ピッチ・放じ山の高さ・谷径の検討）

(a) スギ試験体

\begin{tabular}{|c|c|c|c|}
\hline & & \multicolumn{2}{|c|}{$\mathrm{Sp}-\mathrm{W}(20+0)$} \\
\hline & & 平均値(1) & $2.51 \mathrm{kN}$ \\
\hline & & 変動係数 & $13 \%$ \\
\hline \multicolumn{2}{|c|}{$\mathrm{Sp}-\mathrm{X}(20+0)$} & (1)と(2)の間の & \\
\hline 平均値(2) & $2.44 \mathrm{kN}$ & 有意差検定 & 人 \\
\hline 変動係数 & $16 \%$ & (1)に対する(2)の比 & $97 \%$ \\
\hline \multicolumn{2}{|c|}{$\mathrm{Sp}-\mathrm{Y}(20+0)$} & \multirow{2}{*}{$\begin{array}{c}\text { (1)と(3)の間の } \\
\text { 有意差検定 }\end{array}$} & \multirow{2}{*}{$\bigcirc$} \\
\hline 平均値(3) & $2.33 \mathrm{kN}$ & & \\
\hline 変動係数 & $15 \%$ & (1)に対する(3)の比 & $93 \%$ \\
\hline \multicolumn{2}{|c|}{$\mathrm{Sp}-\mathrm{Z}(20+0)$} & \multirow{2}{*}{$\begin{array}{c}\text { (1)と(4)の間の } \\
\text { 有意差検定 }\end{array}$} & \multirow{2}{*}{$\bigcirc$} \\
\hline 平均値(4) & $2.69 \mathrm{kN}$ & & \\
\hline 変動係数 & $14 \%$ & (1)に対する(4)の比 & $107 \%$ \\
\hline
\end{tabular}

注） ○ : 有意差有り $(\alpha=0.01) 、 O$ : 有意差有り $(\alpha=0.05) 、 X$ : 有意差無し (b) ヨーロッパアカマツ試験体

\begin{tabular}{|c|c|c|c|}
\hline & & \multicolumn{2}{|c|}{$\mathrm{Ap}-\mathrm{W}(20+0)$} \\
\hline & & 平均値(1) & $3.70 \mathrm{kN}$ \\
\hline & & 変動係数 & $11 \%$ \\
\hline \multicolumn{2}{|c|}{$\mathrm{Ap}-\mathrm{X}(20+0)$} & (1)と(2)の間の & V \\
\hline 平均值(2) & $3.53 \mathrm{kN}$ & 有意差検定 & $\lambda$ \\
\hline 変動係数 & $13 \%$ & (1)に対する(2)の比 & $95 \%$ \\
\hline \multicolumn{2}{|c|}{$\mathrm{Ap}-\mathrm{Y}(20+0)$} & \multirow{2}{*}{$\begin{array}{c}\text { (1)と(3)の間の } \\
\text { 有意差検定 }\end{array}$} & \multirow{2}{*}{ (2) } \\
\hline 平均值 (3) & $3.30 \mathrm{kN}$ & & \\
\hline 変動係数 & $12 \%$ & (1)に対する(3)の比 & $89 \%$ \\
\hline \multicolumn{2}{|c|}{$\mathrm{Ap}-\mathrm{Z}(20+0)$} & \multirow{2}{*}{$\begin{array}{c}\text { (1)と(4)の間の } \\
\text { 有意差検定 }\end{array}$} & \multirow{2}{*}{$x$} \\
\hline 平均値(4) & $3.79 \mathrm{kN}$ & & \\
\hline 変動係数 & $12 \%$ & (1)に対する(4)の比 & $102 \%$ \\
\hline
\end{tabular}


をねじ込んだ試験体の最大引き抜き耐力がねじ部のみをねじ込んだ 試験体のそれを上回った。また、その向上率は、ベイマツの 7 11\% に対してスギが 22 26\%を示し、2 倍程度高かった。一方、胴部の 放じ込多深さを増加させても $(15 \mathrm{~mm} \rightarrow 30 \mathrm{~mm})$ 一定以上の性能向 上は見られなかった。

(2)先端部形状の影響 : スギとベイマツのいずれも、先端部形状が異 なる試験体（ドリル刃先とスプーンカット）の荷重一変位挙動や最 大引き抜き耐力にほとんど差が認められなかった。

（2）有効ねじ部の形状因子に関する検討結果

(1) ピッチの影響 : スギとヨーロッパアカマツのいずれも、実験に用 いた木齐じにおけるピッチ変化量 $(0.7 \mathrm{~mm}: 2.3 \mathrm{~mm} \rightarrow 3.0 \mathrm{~mm})$ の範 囲内に限り、引き抜き性能に有意な差は認められなかった。

(2) ねじ山の高さの影響 : スギとヨーロッパアカマツのいずれも、谷 径が同径である場合にねじ山の高さを低くした試験体 $(1.3 \mathrm{~mm} \rightarrow$ $0.65 \mathrm{~mm}$ ）の最大引き抜き耐力が低下寸る結果を示し、叔じ山によ る機械抵抗と引き抜き性能との相関関係が確認できた。その低下率 は、スギで $7 \%$ 、ヨーロッパアカマツで $11 \%$ となった。

(3)谷径の影響 : 山径が同径である場合に谷径を大きくしたスギ試験 体 $(4.4 \mathrm{~mm} \rightarrow 5.7 \mathrm{~mm})$ の最大引き抜き耐力が $7 \%$ 向上し、向上が認 められなかったヨーロッパアカマツと対照的な結果となった。スギ は、ねじ山による機械抵抗と共にねじ谷による摩擦抵抗が引き抜き 性能の向上に寄与するものと推察される。

以上の検討結果を通じて、使用する木材の材料特性によって、木 ねじの各形状因子の引き抜き性能への寄与度が異なる傾向を示寸場 合もあることが確認された。したがって、主に圧密効果に起因寸る と推測される軽軟材特有の傾向を逆に活用し、軽軟材に適した木ね じの形状を考案することで比重差による接合性能の低下を補える可 能性があると考えられる。但し、本論文の結果は木ねじのねじ込み 後 10 分 1 時間ほど経過した時点における実験で得られたものであ り、胴部のねじ込み及び同山径に対する谷径の増大による引き抜き 性能の向上効果を積極的に評価するには、今後、その経時変化につ いて検討する必要がある。さらには、軽軟材の材料特性と引き抜き 性能の発現機構との関係をより明確に把握するために、木ねじと接 触する木材の局部的な圧密を可視化する方法について検討する必要 がある。

\section{謝辞}

本論文は、農林水産省の公募事業、「新たな農林水産対策を推進す る実用技術開発事業」での研究課題「輸出ニーズに適応した建築物 向け国産材インフィル部材の技術開発」による成果の一部である。 また、木称じの周辺技術情報についてご指導いただいた（株）カナ イ、(株) タツミ、東日本パワーファスニング（株）をはじめとする 多くの関係者に感謝の意を表する。

\section{参考文献}

1）白惠琇, 稲元靖教, 飯村豊, 森田秀樹, 椎葉淳, 並木高, 並木龍一, 濱 野裕仁: 低比重材スギ用のビスの開発一ビスの胴部が引き抜き性能に及 ぼす影響一, 第 60 回日本木材学会大会研究発表要旨集(宮崎), H18-1330, 2010.3

2）森田秀樹, 白惠琇, 椎葉淳, 田中洋, 皆内健二, 藤元嘉安, 飯村豊, 大 熊幹章，並木高，並木龍一，濱野裕仁：スギに適した木㸚じ（スギねじ）
の開発一引き抜き試験結果一,第 61 回日本木材学会大会研究発表要旨集 (京都)，D19-P-AM26，2011.3

3) Hei-Soo Baek, Hideki Morita, Atsushi Shiiba, Yutaka Iimura, Fujio Imai : Influence of Shape Factors of Wood Screw on Withdrawal Performance-Development of wood screw used for soft and light wood -, Proceedings of the 12th World Conference on Timber Engineering WCTE2012, Auckland, New Zealand, CD-ROM, 2012.7

4）特定非営利活動法人木の建築フォラム, 宮崎県木材利用技術センター : オビスギにみる現代技術によるスギ材の利用とその展望, 第 7 回木の建 築フォラム/都城・スギシンポジウム $2004,2004.11$

5）白惠琇, 稲元靖教, 飯村豊, 皆内健二：民需用中小規模非住宅木造の軸 組コスト分析一鉄骨造と木造の試設計モデルによる検討を中心に一，第 13 回木質構造研究会技術発表会技術報告集, pp.29 32, 2009.12

6）（財）日本規格協会：日本工業規格 JIS B 1112 （十字穴付き木䣊じ）・ JIS B 1135 （すりわり付き木ねじ），（財）日本規格協会，1995

7）（財）日本規格協会：日本工業規格 JIS B $0101 （$ 永じ用語），（財）日 本規格協会， 1994

8）日本建材新聞社：住宅ジャーナル編 金物工法ハンドブック，日本建材新 聞社・住宅ジャーナル，2006.2

9）(株）カナイ：KANAI TECHNICAL CATALOGUE，No.0902，2009.02

10）(株) タッミ : TATSUMI HOUSE MATERIALS CATALOGUE, Vol.4, 2009.04

11）（財）日本規格協会：日本工業規格 JIS B 1115 (すりわり付きタッピン ねじ）・JIS B 1122 （十字穴付きタッピンねじ）・JIS B 1123 (六角タ ッピンねじ）・JIS B 1125 （ドリリングタッピン稌じ）・JIS B 1126 （つ ば付き六角タッピンねじ）・JIS B 1127 (フランジ付き六角タッピン永 じ），（財）日本規格協会，1995・1996

12）小林研治：木質構造におけるビス接合部の力学特性，木材工業，Vol.64 No.6, pp.252 257, 2009.6

13）中谷誠，小松幸平：ラグスクリューボルトの引き抜き性能発現機構（第 1 報）一先孔直径、埋め込夕深さ、埋め込み方向、縁距離が引き抜き性 能に及ぼす影響一，日本木材学会誌，Vol.51 No.2，pp.125 130，2005.3

14）徳田貴寛，槇谷榮次，夏目正来，島田俊一：金物と木材を接合するビス の引抜抵抗に関する実験研究，日本建築学会大会学術講演梗概集. C-1, 構造 III, pp.39 40，2006.9

15）小林研治, 相馬智明, 稲山正弘, 安藤直人, 青山章一, 秋山信彦：ビス の形状が引き抜き性能に及ぼす影響, 日本建築学会大会学術講演梗概集。 C-1, 構造III, pp.317 318, 2008.9

16) Hirotatsu Mizuno, Yoshiaki Hattori : Withdrawal Strength of Screw with coarse threaded portion on Sugi, Proceedings of the 10th World Conference on Timber Engineering WCTE2008, Miyazaki, Japan, CD-ROM, 2008.6

17）村上了，北守顕久，鄭基浩，森拓郎，小松幸平 : 構造用スクリューの引 抜き挙動に関する研究一ビスねじ山の機械抵抗の影響一, 第 59 回日本木 材学会大会研究発表要旨集（松本），H15-1400，2009.3

18）村上了, 鄭基浩, 中谷誠，北守顕久，小松幸平：スクリュ一型接合具の 引抜き抵抗の検討一径、漦じ山高さ、ピッチの影響一, 日本建築学会大 会学術講演梗概集. C-1, 構造III, pp.189 190, 2010.9

19）（社）日本建築学会：木質構造設計規準 - 同解説一許容応力度 - 許容而 力設計法 - , (社) 日本建築学会, pp.210 221・279 285, 2006

（2012年 8 月 9 日原稿受理，2012年12月27日採用決定） 